\title{
Individualism in a Stable Democracy as the Decisive Factor of the Progress of Behavioralism in the Development of American Political Science Post World War II
}

\author{
Bambang Wahyu Nugroho \\ Jurusan IImu Hubungan Internasional, Fakultas IImu Sosial IImu Politik, Universitas Muhammadiyah Yogyakarta \\ Ringroad Barat Tamantirto, Kasihan, Bantul 55183 \\ Email:bwnugie@hotmail.com
}

\begin{abstract}
Abstrak
Sejak berakhirnya Perang Dunia II, perkembangan ilmu politik Amerika menunjukkan persuasi perilaku yang dominan. Behavioralisme memiliki banyak faktor dan pertumbuhan cepat berdampak besar pada perkembangan studi politik. Bahkan tidak ada yang menampikkan bahwa ilmu politik Amerika adalah ilmu yang berpengaruh dalam kajian politik di seluruh dunia. Singkatnya, dibandingkan dengan dunia lain, perkembangan ilmu politik di Amerika lebih revolusioner. Banyak ilmuwan telah menulis tentang faktor penyebab rapid spring behavioralisme dalam IImu Politik Amerika. Namun, pekerjaan ini dilakukan untuk meneliti faktor-faktor penting lainnya. Pertanyaannya tidak dimulai dari "mengapa Ilmu Politik Amerika berkembang pesat?" Tapi "Mengapa fakta menunjukkan lambatnya pertumbuhan Ilmu Politik di luar Amerika?" Saya berpikir bahwa jawabannya diletakkan pada individualisme sebagai filsofi dan / atau ideologi. Individualisme merupakan keyakinan utama individu terhadap kelompok sosial atau collective body, sehingga ini akan menunjukkan bahwa setiap otang adalah pusat atas teori politik dan penjelasan sosial. Individualisme mempengatuhi Imuwan politik untuk fokus pada unit analisis perilaku individu untuk menjelaskan fenomena kolektif. Bisa dilihat di belahan dunia lain ketika liberal-demokrasi stabil berdasarkan individualisme terjadi, ilmu-ilmu sosial dapat berkembang dengan baik. Mungkin ini adalah karakteristik lain yang unik dari ilmu politik. Pertumbuhan ilmu politik tergantung pada keadaan politiknya.

Kata Kunci:Individualisme, IImu Politik Amerika, Behavioralisme
\end{abstract}

\begin{abstract}
Since the end of World War II, the development of American political science showed the behavioral persuasion as the dominant one. Behavioralism had many factors and its rapid growth had a great impact on the development of political studies. Even in the recent times, no one deny that the American political science is the most influential school on the study of politics all over the world. In short, comparing to the other part of the world, the development of political science in America is revolutionary rather than evolutionary. Many scientists have written about the factors causing the rapid spring of behavioralism in American Political Science. However, this work is done to examine other significant factors. The question does not begin from "why American Political Science growing rapidly?" but "Why facts show us there was a slow motion growth of political science out of America?" I think that the answer is laid on individualism as a philosophy and/or ideology. Individualism is a belief in the primacy of the individual over any social group or collective body, so it will suggest that the individual is central to any political theory or social explanation. Individualism influenced political scientists to focus the unit of analysis on the individual behavior to explain collective phenomenon. We can see then, in other parts of the world, when stable liberal-democracy based on individualism occur, the social sciences can develop well. Maybe this is another unique characteristic of political science. The growth of political science depends on its political circumstances. Keywords:Individualism, American Political Science, Behavioralism
\end{abstract}

\section{INTRODUCTION}

In American political science since the end of
World War II, the behavioral persuasion has been the dominant one. According to Robert Dahl, there are 
six significant factors causing the rapid development of the behavioral approach, i.e (Dahl in Susser, 1992:2746).

1. the inspiration of the schools of political studies concerning to behavioral approach;

2. the immigration to the United States in the 1930 s of large numbers of European scholars (particularly Germans) with backgrounds in European sociology, who stressed the relevance of sociology to politics;

3. the practical roles of many political scientists into administrative and political positions during World War II;

4. the influence of foundation support in the encouragement of research in political behaviour;

5. the increasing development of the survey method in certain political studies, such as voter behaviour; and

6. the missionary work of the Social Science Research Council under leadership sympathetic to behavioralism.

This essay has a significance to be written because we know that the growth of American political studies in the dawn of $20^{\text {th }}$ Century until the recent times has been the most flowering development rather than any other part of the world. Even in the recent times, no one deny that the American political science is the most influential school on the study of politics all over the world, although in some part outside the US we have been seeing another center of growth on the study of politics.

Apart from Great Britain and a few other European nations, the development of political science outside the United States was slow. The Japanese writer Kiheiji Onozuka, indeed, published his Principles of Political Science in 1903, but no significant headway was made in the discipline in Japan until after World War II. Beginnings in the systematic study of political systems were not made in Denmark until 1959, when the Institute of Governmental Studies at the University of Aarhus was founded. The International Association of Political Science, with headquarters in Paris, was just founded several years after the end of World

\section{War II in 1949.}

In Communist regimes around the world, the study of political science was all but impossible until the late 1980s. Since these regimes regarded themselves as having a transitional form of government on the way to the ideal Socialist society, all other political arrangements were viewed as flawed. In 1989, however, the Communist systems of Eastern Europe collapsed, and the Soviet Union entered a period of political instability. Doctrines of Marx and Lenin were abandoned nearly everywhere, and the serious study of other political systems was undertaken (Compton Encyclopedia, 1999). In short, comparing to the other part of the world, the development of political science in America is revolutionary rather than evolutionary.

The slow motion growth of political science out of America, in my sense, is related to the political stability of the nations or areas. From the dawn of Industrial Revolution to the end of the Second World War, we can say that the most part of Europe faced much revolutionary political instability. The two world wars, particularly the second, plunged Europe to the mass destruction, either physically or psychically. Undoubtedly the United States is the only that could be relatively save from the impact of World War II, although economical depression had ever been suffered in the mid-1930s. By the end of World War II, the United States grew as a superpower in economy and politics, which could be competed only by USSR. The difference between them is the spirit of democracy that assured free expression of the people in the US, and the totalitarian regime that restricted the freedom of the USSR's people to think politically alternative.

This essay wants to explain that the spreading of individualism in the context of stable democratic regime circumstance was also a supportive factor beside the former six - causing political scientists in the United States could produce and develop the field of study fruitfully.

My work is divided into four parts. Firstly, I'll review the condition of pre-behavioralism era in American political studies, and secondly, the abstract 
of the nature of behavioralism. Then, I want to elaborate the former six factors and provide evidences that all of these factors were not enough yet. And finally, I want to explain why and how individualism in a stable democratic regime, actually, was the "seventh" significant factor.

\section{ANALYSIS}

\section{A BRIEF REVIEW ON THE PRE-BEHAVIORALISM AMERICAN} POLITICAL STUDIES

Modern political science originated during the $19^{\text {th }}$ century, when people believed that almost any subject matter could be turned into a scientific discipline (Compton Encyclopedia, 1999). Political science was taken up enthusiastically in the United States, a nation with a history of political experimentation. Some of the most notable works on government were written about the American system. The debates about ratification of the Constitution led to the writing of the federalist papers by John Jay, James Madison, and Alexander Hamilton in 1787. In the 1830s Alexis de Tocqueville published his Democracy in America, probably the best analysis of United States political institutions ever written. Two generations later the British writer James Bryce published The American Commonwealth.

Politics has played a significant role in the American consciousness ever since the colonial era. As early as 1642 , before the term political science was coined, Henry Dunster, president of Harvard College, added to the curriculum a course on ethics and politics. In the mid-19th century the president of Yale College, Theodore Dwight Woolsey, introduced a course in political philosophy into the school (Compton Encyclopedia, 1999).

Eventhough, as far as the growth of political science, approaches done by political scientists in the given time just showing that political science is a 'pseudo science.' Political science was close to some like 'art' rather than a science. Two main approaches called normative and institutional or empirical were assumed lack of explanation power -something important as a requirement of a science. Normative approach is the prescription of values and standards of conduct. It talks about what 'should be' rather than what 'is.' While institutional or empirical approach, although was based on observation and experimentation, and the knowledge was derived from sense data and experience, it was seemed descriptive rather than explanative (Heywood, 1997:12-14, marsh and Stoker, 1995). Macridis stated that the major characteristics of the 'traditional' approaches were essentially noncomparative, descriptive, parochial, static, and monographic (Macridis in Susser, 1992:14-22).

The enthusiastic development of social sciences in the $19^{\text {th }}$ century also stimulated as it had been by the rapid growth of the natural sciences, reinforced an existing interest in politics in the United States and created a generation of distinguished American political scientists. There had, in fact, been much interest in the teaching of political subjects in American colleges and universities well before the 19th century.

\section{NATURE OF BEHAVIORALISM}

Definition:Behavioralism is the belief that social theories should be constructed only on the basis of observable behavior, providing quantifiable data for research (Heywood, 1997:14). Actually, behavioral sciences are any of various disciplines dealing with the subject of human actions, usually including the fields of sociology, social and cultural anthropology, psychology, and behavioral aspects of biology, economics, geography, law, psychiatry, and political science. The term gained currency in the 1950s in the United States; it is often used synonymously with "social sciences," although some writers distinguish between them. The term behavioral sciences suggest an approach that is more experimental than that connoted by the older term social sciences.

Although the term behavioralism has been freely used in political-science writings, there is in fact confusion as to whether it is a field of study, a method, or an approach. Behavioural Sciences as a fields of study are primarily concerned with the understanding, prediction, and control of human behaviour, especially those types of behaviour that 
develop out of interpersonal relations. Although many disciplines contribute in part to the science of behaviour, a number of them are so overwhelmingly concerned with past or present behaviour that they can be classed together as the behavioural sciences. These disciplines include anthropology, education, political science, psychiatry, psychology, and sociology. Investigators who work in these areas systematically and experimentally focus their attention on human behaviour as it influences and is influenced by the attitudes, behaviour and needs of other people. A major application of behavioural science has been the prediction of human behaviour. Examples are polling and testing, which include political and marketing surveys, questionnaires, and attitude tests, as well as psychological and industrial uses of tests of aptitude, ability, achievement, and personality (Encarta Encyclopedia, 1998).

One American political scientist, Heinz Eulau, in The Behavioral Persuasion in Politics (1963), has said that the behavioral persuasion "is concerned with what man does politically and the meanings he attaches to his behavior," and he has suggested that researchers cannot afford to get tangled up in problems of definition. Another American, Robert Dahl, has said that it is a mood or even "the scientific outlook." The term behavioral, then, may be merely a term having distinctiveness, weight, and value for a certain time only, since it seems primarily to signify that phase in the quarter century after World War II during which there was a significant revival of interest in empirical studies in politics, a movement strong enough to establish at least a partnership with the traditional approaches, although some of its advocates have gone so far as to say that their science has made traditional approaches outdated. In short, both of them viewed that behavioralism is a method of science.

David Easton has tried to define the varieties current meanings of behavioralism. He said that there is no single way of characterizing to the nature of the assumptions and objectives, the intellectual foundation stones on which behavioralism has been constructed. But he tried to make an itemized list pro- vides a reasonably accurate and exhaustive account of them as follows (Easton in Charlesworth in Susser, 1992:47):

1. Regularities;

2. Verification;

3. Techniques;

4. Quantification;

5. Values;

6. Systematization;

7. Pure Science; and

8. Integration.

\section{ELABORATION OF THE FORMER SIX FACTORS}

Inspiration from the Schools of Political Studies

The principal impetus was provided by what became known as the Chicago school in the mid1920s and thereafter. The leading figure in this movement was Charles E. Merriam, who in 1925 published New Aspects of Politics. The book argued for a reconstruction of method in political analysis, urged the greater use of statistics in the aid of empirical observation and measurement, and postulated that out of the converging interests of politics, medicine, psychiatry, and psychology might come "intelligent social control." The basic political datum for Merriam at this stage of his thinking was "attitude"; hence his reliance upon the insights of psychology for a better understanding of politics. These ideas were not entirely new. Graham Wallas, an Englishman, had said in Human Nature in Politics (1908) that a new political science should be based upon quantitative methods. He also said that serious attention should be given to the psychological elements ("human nature") in political activity, including non-rational acts and the exploitation in political life of subconscious non-rational inferences. The American political scientist and journalist Walter Lippmann had expressed much the same view in Public Opinion (1922). One of those in the Chicago group who carried the connection between politics and psychology quite far was Harold Lasswell, in his Psychopathology and Politics (1930). In Power and Personality (1948) he fused the Freudian categories of the earlier work with subsequent writings 
on power. These two leading expositors of the Chicago school, Merriam and Lasswell, both published books at about the same time that gave a central place to the phenomenon of power in the empirical study of politics. Merriam published Political Power in 1934 and Lasswell's Politics: Who Gets What, When, How in 1936. Merriam undertook to show how power came into being, to describe what he called the credenda, miranda, and agenda of authority (which he tended to equate with power), the techniques of power holders, the defense available to those over whom power is wielded, and the dissipation of power. Lasswell's 1936 work was a naturalistic description of "influence and the influential." Although both were cast in the empirical mode, the second was more successful in this regard than the first, which tended to be abstract and rhetorical. A truly empirical work of the Chicago school that had considerable significance in the development of academic political science was Charles E. Merriam and Harold F. Gosnell's work, published in 1924, on Non-Voting, Causes and Methods of Control, which used sampling methods and survey data. Since then, certainly one of the most successful achievements in empirical political science has been the study of voter behaviour and election results. Although members of the Chicago school insistently professed an interest in value-free political science, they were characterized by two normative predilections-their acceptance of the values of the democratic system and their earnest attempts to improve it through their writings.

What stated by Merriam with the Chicago school of political science was a protest over the older approach, say, the traditional approach. In his presidential address to the American Political Science Association in 1925, Merriam said:

Someday we may take another angle of approach than the formal, as other science do, and begin to look at political behavior as one of the essential object of inquiry (Dahl in Susser, 1992:28).

\section{The Influence of European-born Political Scholars}

The development of American political science in the last quarter of the 19th century was influenced by the experience of numerous scholars who had done graduate work at German universities in which political science was taught as Staatswissenschaft ("science of the state") in an ordered, structured, and analytical organization of concepts, definitions, comparisons, and inferences. To modern readers the work of these scientists often seems somewhat formalistic and institutional in tone and focus. It did represent, however, an effort to establish an autonomous discipline, separate from history, moral philosophy, and political economy. Among them were Francis Lieber ${ }^{1}$ and John W. Burgess. ${ }^{2}$

"By the rose of Hitler's Fascism in Germany at 1930s, the new wave of migration from German to the US began, included many scientists, artists, scholars, and writers. Most of them were Jewish. The most influential person in American science progress was Albert Einstein, and especially in political science were Hans J. Morgenthau and Henry Kissinger."

Some other 20th-century writers who influenced the development of American political science were Arthur F. Bentley, author of The Process of Government (1908); Graham Wallas in Human Nature in Politics (1908); Walter Lippmann, author of Public Opinion (1922); Charles Merriam, author of New Aspects of Politics (1925); Harold D. Lasswell in Politics: Who Gets What, When, How (1936); David Easton, author of The Political System (1953); and Carl Friedrich's Man and His Government (1963) (Compton's Interactive Encyclopedia, 1999).

By the influences of European-born political scientists, the development of American political science was led to a broadening disciplinary horizon. Albert Somit stated that there are several factors contributed to this. Among them was the effort, especially by the behavioralists, to develop models, which can be applied to all political societies, advanced or "developing," Western, or non-Western (Somit and Tanenhaus, 1982).

\section{Practical Roles of Political Scientists}

The roles of political scientists in the 'real' public 
issues have a root in 1865 when the American Social Science Association was founded. According to Somit (1982) when American political scientists studied abroad, especially in Continental Europe, they became surprised by the extent to which continental academicians, particularly those in Germany, participated in governmental and political activities. There were a considerable number of professors who, while carrying on their university duties, take an active part in public affairs. This circumstance heavily influent to the role of American political scientists. Even though their roles ranged wide, we can see their expression on the special scientific journals, Political Science Quarterly. Most of articles in this journal had a particular attention to the "contemporary events" either domestic or abroad. So, these articles dealt with public issues rather than the 'pure' science of politics (Somit and tanenhaus, 1982:42-44).

In the other way, those political scientists also were involving their selves in educating for citizenship and public affairs. They had a responsibility to transmit to their nation's youth the knowledge and the patriotic sentiments deemed essential for the successful functioning of their democratic system (Somit and tanenhaus, 1982:45). Therefore, the scientists did the two unique roles. In one capacity, they had to study and criticize the political order whose virtues he was obligated, in their second role, they praised to defend and maintain democratic system, and transmitted it to the younger generation (Somit and tanenhaus, 1982:46-47)

Such of good start in public education continued and followed by number activities like education for citizenship and public service, education for democratic citizenship, participation in public affairs; and broadening disciplinary horizons. As noted by Dahl, the Second World War also stimulated the development of the behavioral approach in the United States, for a great many American political scientists temporarily vacated their ivory towers and came to grips with day-to-day political and administrative realities in Washington and elsewhere.

The experience of academics who returned to the campus after government service in World War II (1939-1945), had a profound effect on the entire discipline. Employment in agencies polished their skills in applying the methods of social science, including public opinion surveys, content analysis, statistical techniques, and other means of collecting and systematically analyzing political data. Having seen first-hand how the game of politics is really played, these professors often came back to their research and to college classrooms eager to use these tools to determine precisely who gets political power in a society, why and how they get it, and what they do with it.

\section{Influences of Foundation Support}

Foundation is a non-profit organization with funds and programmes managed by its own trustees or directors, established to maintain or aid social, educational, charitable, religious, or other activities serving the common welfare. Although some governmental agencies employ the word foundation in their titles, the term is generally regarded as applying only to non-governmental organizations. The foundation work is carried on by its own staff or by outside organizations or individuals to which grants of money are allocated for use in specific projects (Encarta Encyclopedia, 1998).

The ascendancy of the US as a superpower in world politics meant that the intellectual challenges presented by a global foreign policy have a spillover effect upon the colleges and research institutes of the US. In short, US perception of its new role in macropolitics encouraged a new interest in the subject. In the years after 1945, moreover, funds for basic research were available. The most well known foundations were Ford Foundation, Rockefeller Foundation, and Carnegie Foundation.

During the war he gave up his position to take charge of the eastern military railroads and telegraph lines for the government. After the Civil War he could see that iron bridges would soon replace wooden structures. So he founded the Keystone Bridge Works, which built the first iron bridge across the Ohio River. 
This business led him to found the iron and steel works that brought him the bulk of his huge fortune.

By 1899 Carnegie had consolidated many of the steel works located around Pittsburgh into the great Carnegie Steel Company. Two years later, at the height of his phenomenal business career, he transferred his 500-million-dollar steel interests to the new United States Steel Corporation. He then retired from business so that he could devote his time and money to public service.

Carnegie believed that it was the solemn duty of a rich man to redistribute his wealth in the public interest. He also felt, however, that indiscriminate giving was bad. "No person," he said, "and no community can be permanently helped except by their own cooperation." To insure that his money would be distributed wisely, he established the Carnegie Corporation of New York, with an endowment of $\$ 125,000,000$. The income from this fund now goes to many causes. His biggest gift for any single purpose was the fund for establishing the Carnegie public libraries. Almost as famous are the Hero Funds he set up in many countries to recognize heroic acts that might otherwise go unappreciated.

The table draws to us how much financial support got by many social and/or educational institutions to improve their performance and to produce advancements of life. To see the financial support fund by the three foundations on the efforts to develop American political science, look at the table as follows.

\section{The Increasing Development of Survey Research}

Survey research became the interesting trend as a tool for the study of politics was related to the existence of some common attitudes characterizing the culture of American people:pragmatism, factmindedness, confidence in science, and the development of the use of mathematics on social research, particularly statistics.

Table 3 shows the frequency with which three classes of research methods were used in articles published in the American Sociological Review between 1936-1978. The table also shows the trends in popularity over time.

What drawn in the table above is clear, that in the earliest period, interpretative method and surveys each accounted for about half the articles has published. The years after, when the survey methods substantially growth and popular, the use of interpretative methods declined.

Social scientists can be helped by the advancement of applicable mathematical method to analyze the huge social data, called statistics. Statistics is developed from probability theory, that is the branch of mathematics concerned with the analysis of random phenomena. The entire set of possible outcomes of a random event is called the sample space. Each outcome in this space is assigned a probability, a number indicating the likelihood that the particular event will arise in a single instance. An example of a random experiment is the tossing of a coin. The sample space consists of the two outcomes, heads or tails, and the probability assigned to each is one half.

Statistics applies probability theory to real cases and involves the analysis of empirical data. The word statistics reflects the original application of mathematical methods to data collected for purposes of the state. Such studies led to general techniques for analyzing data and computing various values, drawing correlation, using methods of sampling, counting, estimating, and ranking data according to certain criteria (Compton's Encyclopedia, 1999).

Statistical data are usually collected in one of the following ways:

1) by consulting existing source material, such as periodicals and newspapers, or reports from industries, government agencies, and research bureaus;

2) by setting up a survey and collecting data at first hand from individuals or organizations; and

3) by conducting scientific experiments and measuring or counting under controlled conditions.

The survey methods help social scientists to collect and analyze a huge of social data, whether is primary or secondary data. Whatever data being collected, the 
Table 1. The Twelve Leading Foundations (Ranked According to Total Assets)

NAME; PLACE AND DATE OF DONOR ESTABLISHMENT

Ford Foundation Michigan, Henry Ford, Edsel 1936

Ford

J. Paul Getty Trust California, J. Paul Getty 1953

W.K. Kellogg Foundation W.K. Kellogg

Michigan, 1930

John D. \& Catherine T. John D.

MacArthur Foundation MacArthur

Illinois, 1970

Lilly Endowment, Inc.

Indiana, 1937

Robert Wood Johnson

Foundation New Jersey,

1936

Rockefeller Foundation New

York, 1913

J.K. Lilly, Sr., Eli

Lilly, J.K. Lilly, Jr.

Gen. Robert

Wood Johnson

John D.

Rockefeller, Sr.

Pew Memorial Trust Pennsylvania, 1957

Mary Ethel Pew Mrs. Mabel Pew Myrin, J. Howard

Pew, Joseph N.

Pew, Jr.

Andrew W. Mellon

Alisa Mellon

Foundation Delaware, 1940 Bruce, Paul

Mellon

Kresge Foundation

Sebastian S

Michigan, 1924

Kresge

Duke Endowment New James B. Duke

Jersey, 1924

Charles Stewart Mott

Charles Stewart

Foundation Michigan, 1926 Mott and family

\section{OTHER MAJOR FOUNDATIONS}

Carnegie Corp. of Andrew Carnegie

New York New

York, 191

McKnight

Foundation

Minnesota, 1953

W.M. Keck

Foundation

Delaware, 1954

Gannett

Foundation New

York, 1935

Foundation

California, 1966

Richard King

Mellon

Foundation

Pennsylvania,

1947

New York

Community Trust

New York, 1923

Frank E. Gannett
William L. McKnight, 71 Maude L. McKnight,

Virginia M. Binger,

James $\mathrm{H}$. Binger

(2)

William M. Keck

Mr. And Mrs.

William R. Hewlet

Richard K. Mellon

New York

community

organizations

\section{ASSETS \\ PURPOSE}

(IN MILLIONS

U.S.D)

4,759

To promote public welfare through grants for study of the environment, education, the social sciences, the humanities, the arts, and local, national, and international affairs. Assists developing nations

3,691 To provide grants for study in the fields of visual arts and related humanities.

3,108 To provide funds for programs in health, education, and agriculture. Aids institutions in many countries.

2,271 To provide grants to talented individuals in many areas. To promote mental health, justice and the quality of life, interest in public affairs and media personnel training.

1,914 To provide grants for educational and religious programs and community services in Indiana.

1,804 To provide funds for programs in health care, emphasizing professional education and delivery of health care services.

1,606 To promote the well-being of all humankind through research to end hunger, solve population problems, aid education in developing nations, provide equal opportunity, and improve the environment. Makes institutional grants, conducts research.

1,55 To provide aid for hospitals, schools, and religious institutions and for medical research and community programs.

1,477 To provide grants for a broad range of programs, including education, conservation programs, medical and public health education, population research, and cultural affairs.

1,047 To provide funds for building construction and renovation, schools, health services, care of youth and the aged, conservation, and the arts.

798 To endow Duke University at Durham N.C., and certain other universities and colleges. Makes grants, in the Carolinas, for hospitals, schools, orphanages, and rural Methodist churches and for ministers' pensions.

733 To provide funds for local health, educational and recreational programs. Makes fellowship grants in community education.

715 To promote knowledge and understanding among the people of U.S. and most British dominions and colonies. Makes grants to United States colleges, universities, and professional and educational organizations for research in educational and training programs in public affairs.

To provide grants in the areas of human and social services and the arts to organizations in Minnesota. Conducts research in neuroscience and plant biology.

To strengthen studies in Earth science, engineering, general science, medical research, and liberal arts in educational institutions in southern California.

To provide grants in the United States and Canada in support of journalism and to further the cause of adult literacy.

To promote study in conflict resolution, the environment, the performing arts, and education at the college and university level in the San Francisco Bay area.

To provide grants to promote conservation of natural areas and wildlife and to support cultural and civic affairs, social services, and medical research in Pennsylvania.

To provide a composite of charitable funds for activities and causes that have a particular significance for the New York City area. Also supports a loan guarantee program for commercial lending. 
Table 2. Rockefeller, Ford, and Carnegie Grants to the 10 Major Educational Institutions in Political Science and Related Areas from 1959 to 1964 (Somit and tanenhaus, 1982:168)

\begin{tabular}{lllll} 
UNIVERSITY & $\begin{array}{l}\text { ROCKEFELLER } \\
\text { (USD) }\end{array}$ & $\begin{array}{l}\text { FORD } \\
\text { (USD) }\end{array}$ & $\begin{array}{l}\text { CARNEGIE } \\
\text { (USD) }\end{array}$ & $\begin{array}{l}\text { TOTAL } \\
\text { (USD) }\end{array}$ \\
\hline Harvard & 195,000 & $20,200,000$ & 75,000 & $20,470,000$ \\
Columbia & & $16,775,679$ & 57,000 & $16,832,679$ \\
Univ. of California & 375,000 & $11,321,700$ & 321,000 & $12,017,700$ \\
Chicago & & $5,400,000$ & & $5,400,000$ \\
Johns Hopkins & 500,000 & $3,400,000$ & 250,000 & $4,150,000$ \\
Cornell & & $3,250,000$ & 600,000 & $3,850,000$ \\
Northwestern & & $3,500,000$ & 200,000 & $3,700,000$ \\
Michigan & 206,800 & $3,164,500$ & 200,000 & $3,571,300$ \\
Stanford & & $3,550,000$ & & $3,550,000$ \\
Princeton & 250,000 & $2,596,000$ & 475,000 & $3,321,000$ \\
\hline
\end{tabular}

basic information must be collected in such a way that it is accurate, representative, and as comprehensive as possible. Statistical treatment cannot in any way improve the basic validity or accuracy of the raw data. Methods of collecting data are therefore basic to the whole field of statistics.

The use of statistics, however, began at Sweden, where Herbert Tingsten in his work Political Behaviour:Studies in Election Statistics (1937) gave currency in the title to what was to be the main development in political science after World War II.

\section{The missionary work of the Social Science Research Council}

Dahl stated that possibly an even bigger impetus not unrelated to the effect of the World War II - was provided by the existence of the Social Science Research Council (SSRC). The Council has had an unostentatious but cumulatively enormous impact on American social science. The annual report of the SSRC for 1944-45 indicated that the Council had reached a

... decision to explore the feasibility of developing a new approach to the study of political behavior. Focused upon the behavior of individual in political situations, this approach call for examination of the political relationship of man - as citizens, administrators, and legislators - by disciplines which can throw light on the problem involved, with the object of formulating and testing hypothesis, concerning uniformities of behavior in different institutional settings (Dahl in Susser, 1992:30). emphasis added

In 1945 the Council established a Committee on Political Behavior, with E. Peddleton Herring as the chairman. The three other members were also well known political scientists with a definite concern about the state of conventional political science (Dahl in Susser, 1992:30).

Near the end of 1949, a new SSRC Committee on Political Behavior was appointed V.O. Key as the chairman. He was a political scientist known for his studies of the U.S. political process and for his contributions to the development of a more empirical and behavioral political science. Educated at the University of Texas (B.A., 1929; M.A., 1930) and the University of Chicago (Ph.D., 1934), Key joined the faculty of the University of California at Los Angeles. In 1936-38 he served with the Social Science Research Council and the National Resources Planning Board. He taught at Johns Hopkins University (1938-49) with interruptions for government service with the Bureau 
of the Budget during World War II. He taught at Yale in 1949-51 and at Harvard University from 1951 until his death. In 1942 Key published Politics, Parties, and Pressure Groups, in which he analyzed the part played by organized interests in the political process. His Southern Politics in State and Nation (1949) pioneered in the use of quantitative techniques and was a classic in regional political studies. In Public Opinion and American Democracy (1961) he analyzed the link between the changing patterns of public opinion and the governmental system. He was vigorous in opposing the idea that voters' preferences are socially determined, and in his posthumous work, The Responsible

Electorate:Rationality in Presidential Voting 1936-60

(1966), he analyzed public opinion data and electoral returns to show what he believed to be the rationality of voters' choices. Other works by Key include The Techniques of Political Graft in the United States (1936), A Primer of Statistics for Political Scientists (1954), and American State Politics:An Introduction (1956). He served as president of the American Political Science Association in 1958-59 (Encyclopedia Britannica Deluxe, 2001). This committee has been an active stimulant in the growth of behavioral approach down to the present times.

\section{INDIVIDUALISM IN A STABLE DEMOCRACY:THE SEVENTH FACTORS?}

Theoretically, individualism is one of elements of liberalism (Heywood, 1997:41). As a philosophy, individualism involves a value system, a theory of human nature, a general attitude or temper, and belief in certain political, economic, social, and religious arrangements. The value system may be described in terms of three propositions:all values are mancentred-that is, they are experienced (but not necessarily created) by human beings; the individual is an end in himself and is of supreme value, society being only a means to individual ends; and all individuals are in some sense morally equal, this equality being best expressed by the proposition that no one should ever be treated solely as a means to the well-being of another person. The individualistic theory of human nature holds that the interests of the normal adult are best served by allowing him maximum freedom and responsibility for choosing his objectives and the means for obtaining them, and acting accordingly. These belief follows from the conviction that each person is the best judge of his own interests and, granted educational opportunities, can discover how to advance them. It is also based upon the assumption that the act of making these choices contributes to the development of the individual and to the welfare of society-the latter because individualism is thought to provide the most effective incentive to productive endeavor. Society, from this point of view, is seen as only a collection of individuals, that each of which is a self-contained and ideally almost self-sufficient entity. As a general attitude, then, individualism embraces a high valuation on self-reliance, on privacy, and on respect for other individuals. Negatively, it embodies

Table 3. Classification of ASR Articles by primary Method of Data Collection

\begin{tabular}{lllll}
$\begin{array}{llll}\text { METHOD OF DATA } \\
\text { COLLECTION }\end{array}$ & $\begin{array}{l}\text { TIME PERIOD } \\
1936-49\end{array}$ & $1950-64$ & $1965-78$ & $\begin{array}{l}\text { TOTAL } \\
1936-78\end{array}$ \\
\hline Interpretative & $51 \%$ & $27 \%$ & $17 \%$ & $31 \%$ \\
Survey & $48 \%$ & $70 \%$ & $80 \%$ & $67 \%$ \\
Experimental & $1 \%$ & $3 \%$ & $3 \%$ & $2 \%$ \\
$\mathrm{~N}$ & $(137)$ & $(200)$ & $(152)$ & $(489)$ \\
& & & & $100 \%$ \\
\hline
\end{tabular}

Source:Adapted from Richard H. Wells and J. Seven Picou, American Sociology: Theoretical and Methodological Structure (Wash. DC., Univ. Press of America, 1981) p. 115 as quoted by Earl Babbie, The Practice of Social Research, $3^{\text {rd }} \mathrm{ed}$., (Cal., Wadsworth Publ. Co., 1983) p. 95. 
opposition to authority and to all manners of control over the individual, especially when they are exercised by the state. It also anticipates and values "progress" and, as a means to this end, subscribes to the right of the individual to be different from, to compete with, and to get ahead of (or fall behind) others. The institutional embodiment of individualism follows from these principles. Only the most extreme individualists believe in anarchy, but all believe that government should keep its interference with human lives at a minimum and that it should confine itself largely to maintaining law and order, preventing individuals from interfering with others, and enforcing agreements (contracts) voluntarily arrived at. The state tends to be viewed as a necessary evil, and the slogan "That government that governs least governs best" is applauded. Individualism also implies a property system according to which each person (or family) enjoys the maximum of opportunity to acquire property and to manage and dispose of it as he sees fit. Freedom of association extends to the right to join (or to refuse to join) any organization. Although instances of individualism have occurred throughout history in many cultures and times, full-fledged individualism, as it is usually conceived to be, seems to have emerged first in England, especially after the publication of the ideas of Adam Smith and Jeremy Bentham and their followers in economic and political theory. Smith's doctrine of laissez-faire, based upon a profound belief in the natural harmony of individual wills and Bentham's utilitarianism, with the basic rule of "each to count for one and none for more than one," set the stage for these developments. On the economic side, Smith's "obvious and simple system of natural liberty" pictured exchange of goods and services in free and competitive markets as the ideal system of cooperation for mutual advantage. Such an organization should maximize efficiency as well as freedom, secure for each participant the largest yield from his resources to be had without injury to others, and achieve a just distribution, meaning a sharing of the social product in proportion to individual contributions. Although economic individualism and political individualism in the form of democracy advanced together for a while, eventually they proved incompatible as newly enfranchised voters increasingly came to demand, in the course of the 19th century, governmental intervention in the economic process. In point of fact the reasons for the growing demand for intervention were inherent in the attempt to adhere rigorously to an economic theory based almost solely on individualistic assumptions. In economics as in all other phases of life, these assumptions are inadequate. Man is a social animal. His nature, his wants, and his capacities are to a great extent the product of society and its institutions. His most effective behaviour is often through groups and organizations, running the gamut from the family through all manners of voluntary social and economically motivated associations to the state and international organizations. These units in varying ways interfere with the individualistic ideals of perfectly free association and of atomistic competition. Problems of monopoly and of technology, seasonal and cyclical unemployment, frequently associated in the public mind with individualistic economic theory, caused widespread dissatisfaction. The prestige of individualistic ideas declined during the latter part of the $19^{\text {th }}$ century and the first part of the $20^{\text {th }}$ with the rise of large-scale social organization. One consequence of this was the emergence of theories calling for the organization of society on principles diametrically opposed to those of individualism. In liberal democracies, however, the notion of the importance of the individual has survived, providing a check on the tendency toward depersonalization that, some say, is a consequence of collectivist trends (Encyclopedia Britannica Deluxe, 2001).

Because of individualism is a belief in the primacy of the individual over any social group or collective body, it will suggests that the individual is central to any political theory or social explanation. And since individualism is the core principle of liberal ideology, together with another elements of liberalism, say, freedom, reason, equality, toleration, consent, and constitutionalism, they build the ideology of liberalism which demand a minimum role and influence of 
state, government or other social collectivism to the individual life. By other word, individualism helps individual to appear in the surface of observation as a significant, even determinant, factor. Contrarily, in the circumstances that individuals are repressed and restricted by collectivism, like in an authoritarian, fascism, or communism regimes, individual seems not too important element of social observation.

\section{CONCLUSION}

The individualism, I think, influenced political scientists to focus the unit of analysis on the individual behavior to explain collective phenomenon. It was hard to research and analyze social institutions directly without defining its unit of analysis. They thought that individual behavior is the core representing social behavior which is easier to be surveyed directly.

Thus, the combination of the need to explain social phenomena scientifically by individual as the main unit of analysis, and the rise of liberal-individualism in the stable democratic regime in the United States post World War II made behavioral approach flowering by the era.

We can see then, in another part of the world, when stable liberal-democracy appear, so the social sciences develop. Maybe that is another unique thing of political science. Natural - or hard -- science can be developed nothing to do with any social and political condition, like in the middle of war situation or in a very authoritarian regime, its experts can make many invention and development of armaments technology based on natural sciences ${ }^{3}$. However, the behavioral political science is not like that. The growth of behavioral political science as a branch of social sciences depends on its social circumstances, especially its political culture. The more free the political-life, the more develop the behavioral political science.

\section{ENDNOTES}

1 The first permanent professorship in political science was created at Columbia University in 1857. He was the first man teaching the course, author of On Civil Liberty and Self-Government (1853). Born at Berlin on March 18, 1798, he had original name Franz
Lieber, German-born U.S. political philosopher and jurist, best known for formulating the "laws of war." His Code for the Government of Armies in the Field (1863) subsequently served as a basis for international conventions on the conduct of warfare. Lieber was educated at the university at Jena. A liberal political activist, he was twice imprisoned under the Prussian government. He fled to England and, in 1827, immigrated to the United States. There he began to compile and edit the first edition of the Encyclopedia Americana (1829-33). He was appointed professor of history and political economics at South Carolina College (Columbia) in 1835 and joined the faculty of Columbia College, New York City, in 1857. During this period he produced two of his most important works, Manual of Political Ethics, 2 vol. (1838-39) and On Civil Liberty and Self-Government, 2 vol. (1853). In his Code for the Government of Armies, drafted for the Union Army during the U.S. Civil War, Lieber recognized the need for a systematic, institutionalized code of behaviour to mitigate the devastation of war, protect civilians, and regulate the treatment of prisoners of war. He died on Oct. 2, 1872 in New York City.

2 In 1880 a whole school of political science was established at Columbia by John W. Burgess, who had studied in Paris at the Ecole Libre des Sciences Politiques (Free School of Political Sciences). In the same year the Academy of Political Science was founded. Another professional organization, the American Political Science Association, was founded in 1903

3 Nuclear, chemical and/or biological weapons can be developed in both democratic or non-democratic regime, for example, in the US or Iraq.

\section{REFERENCES:}

Babbie, Earl. The Practice of Social Research, $3^{\text {rd }}$ ed., Wadsworth Publishing Co., Belmont, California, 1983.

Charlesworth, James C. ed. Contemporary Political Analysis, The Free Press, New York, 1967.

Heywood, Andrew. Politics, Macmillan Press Ltd., London, 1997.

Marsh, David \& Gerry Stoker. Theory and Methods of Political Science, Macmillan London, 1995.

Somit, Albert and Joseph Tanenhaus, The Development of American Political Science, from Burgess to Behavioralism, Irvington Publishers, Inc., New York, 1982.

Susser, Bernard. Approaches to the Study of Politics, Macmillan Publishing Company, NY, 1992.

\section{Another Resources:}

Compton's Interactive Encyclopedia Deluxe (C) 1999 The Learning Company, Inc.

Encyclopaedia Britannica Deluxe 2001.

Microsoft $®$ Encarta $® 99$ Encyclopedia. (C) 1993-1998 Microsoft Corporation. 